JIP, Vol.8, No. 1, Edisi Januari 2018, Hal: 1-12

Agus Sholeh

\title{
Reviving Reading Culture: \\ Promoting Free Voluntary Reading Among Students: The Students' Case Of Priveate University In Malang
}

\author{
Agus Sholeh \\ Universitas Kanjuruhan Malang \\ Sholeh_agus@unikama.ac.id
}

\begin{abstract}
This article concerns with low reading habit and reviews the teaching of EFL reading especially in some private university in the Indonesian. It discusses the activity to revive reading habit by using Free Voluntary Reading as strategy to promote students reading. This research focused on the picture of the implementation FVR, the improvement of students' reading ability and the level of comprehension that can be enhanced. The study figures out that FVR make better their reading habit since the majority students better enjoy reading at home over the previous year a) Most of the students liked the freedom to choose their own books, like talking books and loved learning club, b) Some of the students said that reading is sometimes fun, often fun, usually fun, always fun, but no student who says that reading is not fun.

Key words: Reading, Free Voluntary Reading
\end{abstract}

\section{INTRODUCTION}

This research concerns with the students reading habit since it is far away for their actual life. This study also aimed to increase literacy "reading skills" that must be possessed by students so that students are able to understand the English text well. In many cases, reading activity is not habit for many students because they do not feel that reading is a part of their needs, so they do not spend a lot of time to read either on campus or at home, they use their time to chat with friends or operate their smartphone just for or communicate in their social networks. Actually reading should be activities that are indispensable for the students because by reading they gain useful knowledge for their future and especially to improving literacy "reading skills" that must be possessed by students, so the lack of reading interest of students resulted in a low students' ability to understand English texts. Low habits and ability to read are also experienced by students majoring in English Education of some private University in Malang.

Improving the habit of reading and reading skills takes time and a continuous process to improve the reading motivation of students and requires a learning approach and strategies that correspond to the learning 
objectives and the needs of the students to achieve the learning objectives and need to be supported by a program of study in the form of policy. As a matter of fact that low reading interest of students in English literature resulted in poor Indonesian students' ability to understand English texts. It needs special attention from particularly teachers and practitioners of education to use strategy such as Free Voluntary Reading (FVR).

This research focused on the following issues: 1). How is the picture of the implementation of activities Learning Model Free Voluntary Reading Strategy on the activities of learning to read? 2) How Learning Model Free Voluntary Reading Strategy can improve students' reading ability? 3) At the level of comprehension which students can be enhanced through learning-based Free Voluntary Reading Strategy.

\section{READING AND FREE}

\section{VOLUNTARY READING}

Reading Comprehension should be regarded as a fun knowledge transfer (Rivers, 1981). Further Alderson defines reading as "intense personal activities and fun where information can be obtained in a fun way (Alderson, 2000, P. 8). This is a process where the relevant knowledge to be activated in language skills for the exchange of relevant information. This necessary for the reader to focus on reading material and integrate previously acquired knowledge and skills to understand what others have written (Shahmohammadi, 2011).

The purpose of reading is to understand or grasp the message or author information. When readers do not understand, they do not read. So, on this definition, read for the purpose of improving pronunciation, practicing forms of grammar and vocabulary learning reading skills not because it is not involved in understanding (Chastain, 1988).

According to Ahmadi Gilakjani et.al (2012) reading is an interactive process that is mediated between reader and text. The fundamental concept is that the reader reorganize the information provided in the text not only based on knowledge achieved from the text but also of any prior knowledge of the reader. Hernandez said that reading as an active process and refers to the 
interaction of the different constituents of skills in concurrent operation; interactions affect cognitive skills and good understanding in reading.

Hernandez (2003) states that reading comprehension is assumed to be the ability to construct meaning before, after and during reading through linking reader's background knowledge and the information presented by the author in the context. It is constructing an acceptable accurate meaning by making the connection between what has been read to what the readers already know and think about all of this information until it is recognized (Ahmadi Gilani, et.al 2012).

Harvey and Goudvis (2000) classify reading comprehension into five types: 1) Lexical Comprehension" Understanding the key words in the text reading", 2) Literal Comprehension "Answering questions about the text "who, what, where, when", 3) Interpretive Comprehension "Answer questions about reading why, how", 4) Applied Comprehension "Connecting the content of reading to knowledge or experience of the reader have", 5)
Affective Comprehension" Understand the social and emotional aspects"

Free Voluntary Reading (FVR) is a strategy to motivate students to read the "silent reading" and read a book in the select his own "self-selected reading" the books are fun accordance with the level of independence and student preferences. FVR involves the effectiveness of English major students to explore many books were read and increase the strength or desire to know the benefits of reading (Hernandez, 1997).

Voluntary reading (FVR) means reading as you want and what you want, without any accountability or a book report. This is a very pleasant way to discover our talents, develop some competencies that help to better the way we select, and develop ideas on how to use our talent (Krashen, 2016)

In Free Voluntary Reading students are given the opportunity to choose their own text and read on their own, often with little or no feedback given. Many teachers in the United States believe that reading the voluntary promoting reading skills include word recognition, fluency, and comprehension. Furthermore, the teachers think of reading as the main 
way to increase vocabulary, conceptual understanding, and knowledge of the world (White and Kim, 2008)

In this activity, the student is actually free to choose the materials they want to read, lecturers or teachers constantly motivate students to volunteer to read, students are also given the opportunity to evaluate to report what they've read.

Kim and White (2008) further explained that if students spend more time to read, they will learn to read better, which in turn will lead to more reading. This, in turn, will bring substantial benefits in their lives in the long run.

FVR stages in implementing the program are as follows:

a. Identify the level of independence of students in reading

In this stage to identify the level of independence of our reading class students and also collect some books that correspond to their level. Manage the book so as students easily access what they want to read.

b. FVR Program explain to students
Lecturer introduce or explain FVR program to students, faculty need to explain that reading helps them learn new vocabulary and improve reading skills, word pronunciation, grammar and grammar tau them despite what they read is not reading difficult. Manage system and management consultancy brand book so easy to borrow books easily.

c. Discusses the book in a group

Lecturer schedule a formal literature so that students can share information about books they like and about the authors they like. On this occasion, students have the opportunity to get feedback and suggestions from students who had read many books.

d. Continually motivate students Lecturer always take the time to motivate students who have read the book to celebrate every month or every semester.

e. Evaluate or assess student progress in reading.

Lecturers provide logbook to be filled by students about the books 
they've read or have them read to know that their reading skill level increases.

Kim and White (2008) has conducted experimental research by conducting experiments with four groups of students in grades 3 through 5:

1. The appropriate books alone (Matched book only)

2. Appropriate books and reading oral (Matched books and oral reading scaffolding)

3. Matching books, oral reading and comprehension strategies
(Matched Books with Oral Reading and Comprehension Scaffolding)

4. The control group received a book on a half after the holiday season post-testing and without teachers or parents scaffolding (Control)

To determine the extent to which participants have read the book, the students are given forms as follows:

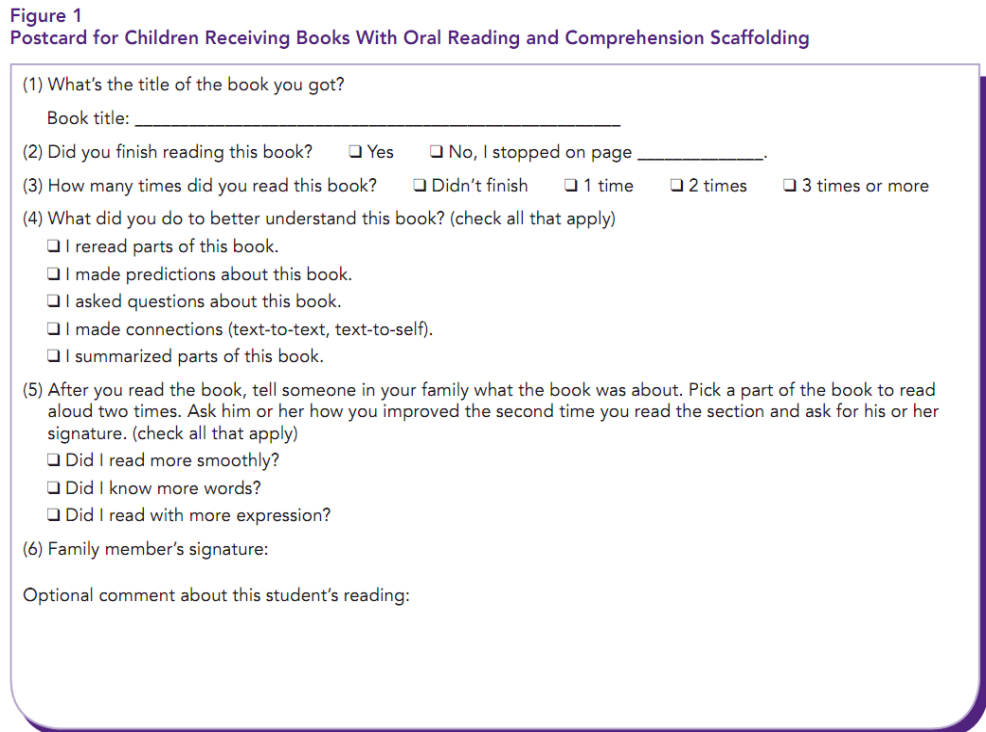

\section{RESEARCH DESIGN}

The study design used is descriptive qualitative since some qualitative characteristics contained in analyzing the data. First, the study was based on a real or natural setting that is based on real conditions. Second, the research data is 
in the form of student learning outcomes in the form of reading comprehension. Third, this study relate to the context of language use. The third reason is in line with the opinion of Bogdan and Biklen (1998) which says that the descriptive qualitative has five characteristics, namely: naturalistic, descriptive, process, inductive, and meaning.
So this study emphasizes descriptive data describing phenomena image of something rather than the data in the form of numbers. This study tries to find out if the Learning Model FVR is able to improve the reading skills of students in the subject of reading so that students can achieve a good reading comprehension

The research design is structured to following figure.

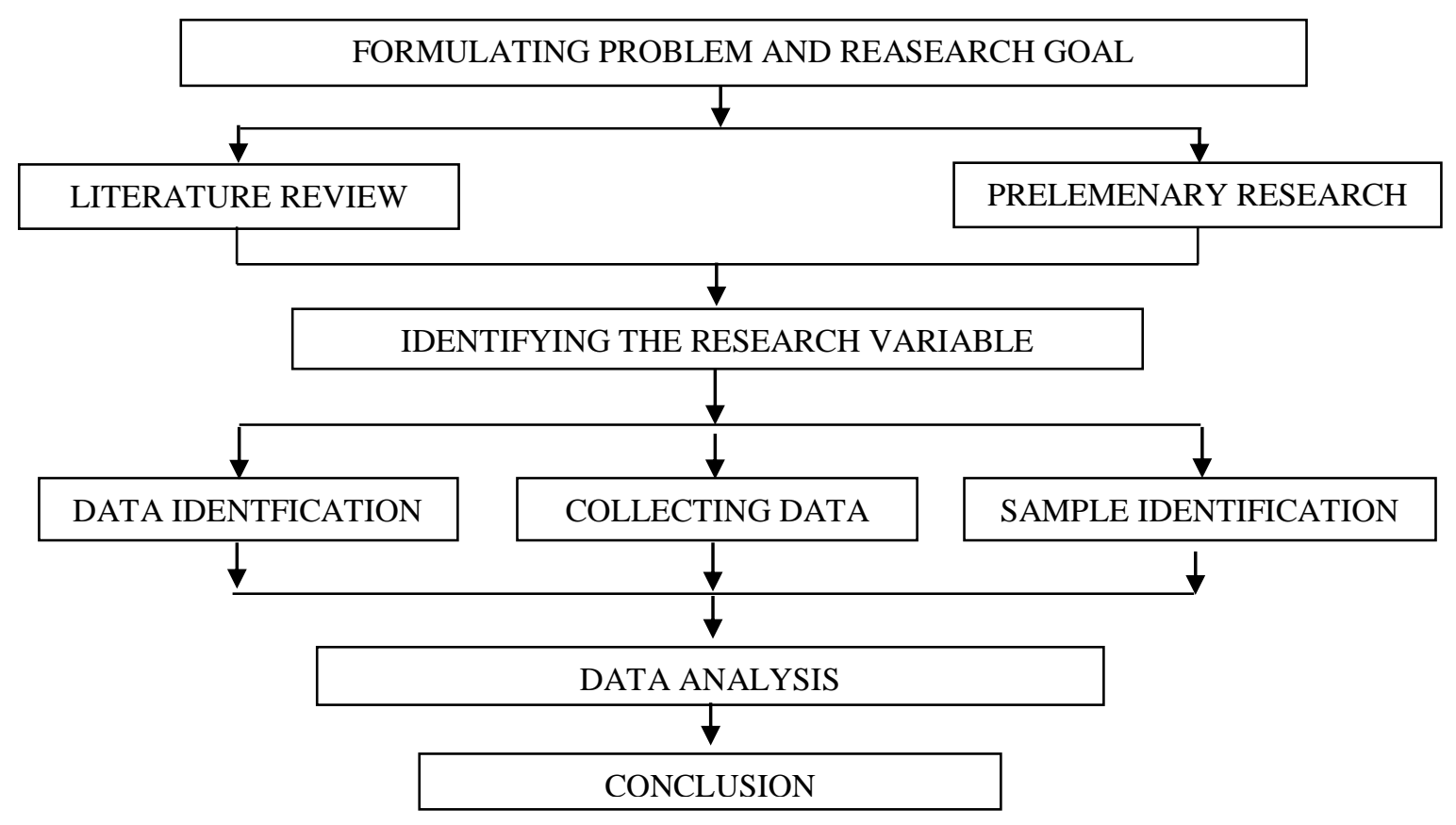

\section{PROCEDURES PROCESSING AND DATA ANALYSIS}

Researchers used the description in the processing and analysis of data on the implementation of Learning Model FVR. At this stage the collected data obtained from observation sheet. 


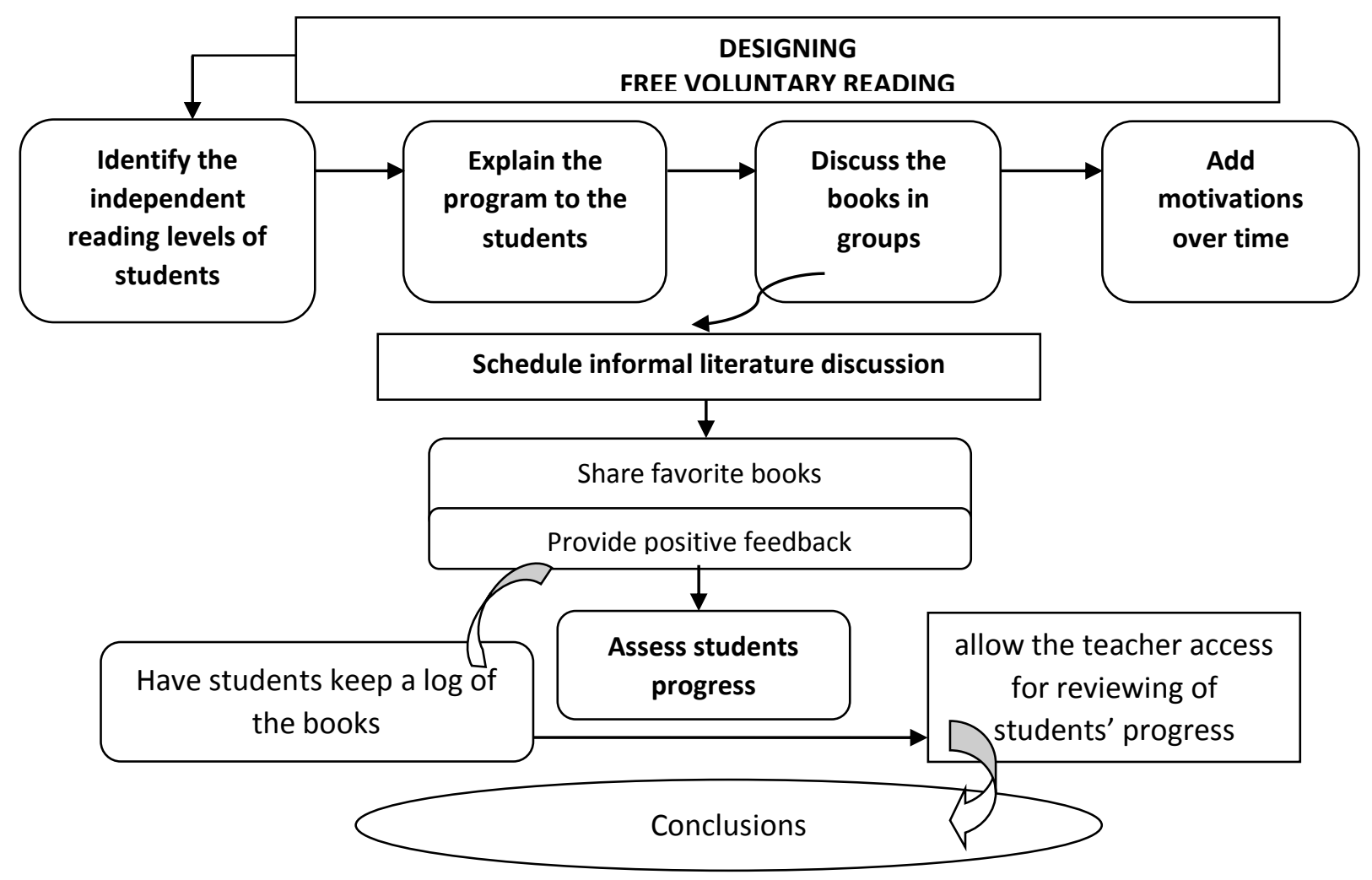

FINDING AND DISCUSSION IMPLEMENTATION OF FREE VOLUNTARY READING

Based on the analysis of ratings based reading assessment rubric, the implementation of free voluntary reading proven to help students improve their reading skills, as reflected in the increased value - average student on reading ability in the subject of reading after they get treatment of free voluntary reading. This is consistent with the findings Charm et al (2007) concluded that there is significant correlation between the ability of Reading students with classroom activities that emphasizes content and language discussion. It is quite reasonable that the content of the topic being discussed, then the student is able to make summary about the topic they are reading. It is very closely related also with content familiarity or knowledge of students about the content of reading.

The fifth component of rubric read, proved that four out of five of these components had significant increases based on the statistics, namely: content, 
organization, vocabulary, and grammar. The increase was due to discuss the activities of reading content before they read, although they are still a lot of discussion. And in the learning process with free voluntary reading students also borrowing or borrowing a word from the text they read.

But the mechanics components, although there is an increase in value compared to pretest posttest, was not statistically significant differences. This may be caused by too little improvement or less conscientious students on the use of capital letters and punctuation.

In learning the English language, both as a second language and as a foreign language, free voluntary reading is helping students improve Reading them as proposed ole Early (1990) that "this approach is valuable in that it enables low English proficiency students to work with academic context and discourse "(free voluntary reading greatly assist students in terms of context and topics discussed). In addition, Madrid (2001) states "Reviews those related to the context and the nature of language instruction are decisive. The effect and value of the language used for classroom instruction is of paramount importance "(the learning associated with the context and nature of language learning are indispensable because they are very important in teaching and learning in the classroom).

In the implementation of free voluntary reading, further stated by Shi (1986), "A rationale is presented for Adopting content-based instruction to meet ESL composition goals; it is argued that such instruction develops thinking, researching, and Reading skills needed for academic Reading tasks and does so more realistically than does traditional instruction that isolates the rhetorical patterns and stresses Reading from personal experience ".(Free voluntary reading increases the ability to think, searching, and reading skills needed in academic settings Reading).

\section{Results of The Student \\ Questionnaire}

1. Twenty-three parents respond to two survey questions.

a. Compared to last year, how much time do you spend reading at home? The old man said: 
JIP, Vol.8, No. 1, Edisi Januari 2018, Hal: 1-12

Agus Sholeh

* Less - None

* The same - 30 percent

(7)

* More - 70 percent (16)

b. How do you seem to enjoy reading

this year compared to last

year? The old man said:

* Less - None

* The same thing - 9

percent (2)

* More - 91 percent (21)

2. Students' response to the Free

Voluntary Reading (FVR)

Children respond positively. They love

freedom. They love

talking about books.

They love the club. A more formal

survey verified their

findings. Students'

responds are the following:

a. How do you assess the reading as an

activity that brings you

pleasure?

* Unpleasant - None

* Sometimes fun - 38

percent (11)

* Usually fun - 21

percent (6)

* Often fun - 24 percent
* Always fun - 17

percent (5)

b. Describe the practice of home-read you.

* I am a stickler read. I read all the time. - 13

percent (4)

* I prefer to read at home at least once a day because I wanted to. - 31 percent (9)

* I prefer to read at home often, but maybe not every day. - 23 percent (7) * When I have free time, I sometimes choose to read at home. - 13 percent (4)

* I do not usually choose to read in my spare time, but I read when I should. 13 percent (4)

* I do not like reading at home, but I do it because the teacher or my parents expected me to. - 7 percent (2)

* I hate to read. Reading 
JIP, Vol.8, No. 1, Edisi Januari 2018, Hal: 1-12

Agus Sholeh

is not fun. I do not do it

unless I have to. - There is

no

c. When finished with the book, I

wanted to ... [Note:

Students are required to

check which statements are applied;

some students were tested

more than one

option.]

* Do a book report -

None

* Is talking books - 21

percent (8)

* Discuss the book with

others - 21 percent (8)

* Writing in my journal

about the book - None

- Start another book - 55

percent (21)

* Other - 3 percent (1)

d. Have to write or create something

after reading for fun

makes reading ...

* Very nice - 11 percent

* More fun - 25 percent

(7)

- Less fun - 46 percent
- boring - 18 percent (5)

\section{Conclusions}

After checking the results of the study, the researchers can draw conclusions from the responses of parents of students as follows: a) Most (70\%) students spend more time to read a book at home over the previous year, b) The majority (91\%) students better enjoy reading at home over the previous year.

While from the students themselves, researchers can draw the following conclusion: a) Most of the students liked the freedom to choose their own books,like talking books and loved learning club, b) Some of the students said that reading is sometimes fun (38\%), often fun (24\%), usually fun (21\%), always fun (17\%); but no student who says that reading is not fun.

On reading activities at home, the student answers vary: fanatical reading (13\%), reading at home at least once a day $(31 \%)$, reading at home but not every day $(23 \%)$, reading when have free time (13\%), read when required (13\%), 
reading for teachers or parents expect students to read (7\%); but no students who say they hate reading.

For a questionnaire about what students do after they finish reading a book, then Answer them as follows: began to read other books (55\%), whether talking books (21\%), discuss books with other people $(21 \%)$, others (3\%); but no student reports on books read.

About a desire to write or create something after reading the book, then answer the following students: less fun (46\%), more fun (25\%), very pleasant (11\%), and boring (18\%).

The findings of the above it can be concluded that students prefer when they are free to choose their own books to read. Therefore Free Voluntary Reading Strategy is very appropriate to be applied to the students to their ability and love of reading is increased.

\section{Suggestions}

Researchers propose some suggestions to be some party in relation to the results of this study: Students should be given the freedom to choose their own books they read in accordance with each student's interest. It will be able to increase their reading fluency and learners in college are recommended to students to read a lot of books to expand your knowledge and insight because the material obtained in college will not be enough. So students should actively read a lot of material.

To facilitate reading for the student researcher suggested to the management body colleges to increase the number of books for students. This will greatly help the students to achieve more leverage in their studies

\section{REFERENCES}

Ahmadi and Gilakjani.(2012). Reciprocal Teaching Strategies and Their Impacts on English Reading Comprehension, Theory and Practice in Language Studies: Academy Publisher. Finland

Alderson, C.J. (2000). Assessing Reading, Cambridge University Press.

Bogdan. C and S. K. Biklen. (1998). Qualitative Research in Education. London: Allyn and Bacon.

Burns, P.C. et al. (1996). Teaching Reading in Todays' Elementary School. Boston: Houghton Mifflin

Cahyono, B.Y. \& Widiati, U.(2006). The Teaching of EFL Reading in the Indonesian Context. The State of 
the Art. TEFLIN Journal, 17(1): 37-56

Chastain 1988 : Reference : Chastain, Kenneth. 1988. Developing second language skills: Theory and practice. 3rd edition. San Diego.

Harvey and Goudvis,(2000). Reading comprehension and student learning and to experiment with new ideas. Stenhouse Publishers

Hernandez, (2003).

Reading Comprehension Requires Knowledge of Words. American Educator. Spring 2003

White and Kim, (2008). "Scaffolded" voluntary summer reading program. University of Virginia Krashen, (2016). Compelling reading and Probling Solving (and the only way) to high levels of language. literacy and life competence.. twenty fifth of international symposium on language teaching, English teachers. Republict of China. Pp. $115-125$

Lam, W.Y.K. (2010). Metacognitive Strategy Teaching in The ESL Oral Classroom. Australian Review of Applied Linguistics. Vol. 33 (1)

Oxford, L.R. (1990). Language Learning Strategies. Boston: Heinle \& Heinle Publishers

Rivers, W., M. (1981). Teaching foreign language skills in a foreign language skills. Chicago: University of Chicago Press

Shahmohamadi, (2011). Study of Emotional Intelligence and Learning Strategies, Volume 29, 2011, Pages 1824-1829

Zimmerman, (1990).Self Regulated learning and Academic Achievement: an interview Educational Phsycologist, 25 (1) (1990), pp 3.17 